\title{
The Use of the Plasma Jet and Laser Photobiomodulation in the Treatment of Alopecia Areata: Case Study
}

\author{
Carla Barreto Silva de Cerqueira ${ }^{1}$, Elisama Adorno Brito ${ }^{1}$, Mylana Almeida de Carvalho ${ }^{2}$ and Alena Ribeiro \\ Alves Peixoto Medrado ${ }^{3 *}$
}

${ }^{1}$ Physiotherapy Course, Science Health Institute, Federal University of Bahia, Brazil

${ }^{2}$ Department of Physiotherapy, UNIJORGE, Brazil

${ }^{3}$ Department of Bio-interaction, Science Health Institute Federal University of Bahia, Brazil

Submission: April 13, 2021; Published: April 28, 2020

*Corresponding author: Alena Medrado, Department of Bio-interaction of Health Science Institute, Federal University of Bahia, Brazil

Abstract

Alopecia is a dermatological disease featured by the absence or shortening strand of hair, either transitory or permanent, which negatively impacts on life quality of those people. This study aimed to report by using photo documentation the efficacy of laser photobiomodulation associated to plasma jet in treating alopecia areata of a 38 years-old woman patient. She came to a private clinic of dermo functional treatment in Salvador, Bahia, Brazil claiming for acute hair loss. It was done 14 sessions of treatment along three months associated to laser photobiomodulation therapy and Plasma Jet. As a conclusion, the comparative analysis of pictures has proved that such therapy associated with laser photobiomodulation plus plasma jet in conductive mode was efficient in treating alopecia areata.

Keywords: Alopecia; Alopecia areata; Plasma jet; Low-power laser

Abbreviations: LED: Light Emitting Diode; TGF-ß3: Transforming Growth Factor Beta3; EGF: Epidermal Growth Factor; NO: Nitric Oxide; HGF: Human Growth Factor; HA: Hyaluronic Acid

\section{Introduction}

Alopecia is a dermatologic disease known by absence or reduction of hair growth as a transitory or permanent way. It may affect even male or female impacting negatively on life quality of those who suffer from that and triggering psychological effects which influence on self-esteem or even contribute for developing depressive stage [1]. In women that impact might affect them more strongly than men since hair means femininity and sensuality in what is seen as face "frame" [2]. Male alopecia is more frequent when compared to women alopecia. It predominantly occurs from 15 to 39 years-old in men while in women it takes place after 50 years-old $[3,4]$. There are several reasons which may lead to hair loss. It can be mentioned bad nutrition mainly caused by low nutrient consumption, emotional factors as stress and anxiety, and pregnancy once during that stage it takes place a series of hormonal changes that affects directly on hair loss process [2]. Since it is known that alopecia may disturb many people and its cause can be different to everyone, it becomes relevant to study therapies able to retard hair losses as well as stimulate growth of new strand hair in the affected area. Among the different resources already searched in literature looking for alopecia, the most relevant is photobiomodulation. This electro therapeutic method has a photobiomodulation action and might be applied for aesthetic or pathologic reasons as well. Laser is able to modulate the healing process and it is possible due to its high capacity to stimulate collagen's production, and promotes increase of local microcirculation with high supply of oxygen and nutrients. It also induces changes in hair density, cuts down secretive activity of chemical mediators and acts as analgesic and anti-inflammatory [5]. 
Another resource which has intensively been researched is plasma jet. That equipment can lead to facial renewing since its actions of reducing wrinkles and expression lines. It works by discharging a continuous electric chain able to stimulate the tissue and epithelium cells. Plasm jet also unleashes retracting on elastic fibers and vasodilation because of increase of local temperature $[6,7]$. A commonly used resource in clinical practice is the photodocumentation once by using photography it is possible to assure to professionals all characteristics pre-existing in a patient before starting the therapy as well as to compare before and after treatment aiming to see all obtained results. That technology has been used in scientific research with the same goal. Additionally, catching images is an important tool for objective analyses being able to measure efficacy of a certain treatment [8]. Thus, this study aimed to document through photographic registers a clinical result of a woman patient who suffers from alopecia areata treated with laser photobiomodulation, plasma jet and active's association.

\section{Case Study}

A 38 years-old patient arrived in a private clinic of Dermatofuncional treatment in Salvador, Bahia, Brazil claiming acute hair loss in her head. She reported that had realized her hair loss started around 60 days ago and did not ask for any professional help before as well as did not take any drug, vitamin or formulation. The patient previously diagnosed with alopecia areata was submitted to professional assessment which began by anamneses and after a scrutinous inspection in the scalp. In the end, she signed an informed consent form and also a photographic authorization after discussing all stages of therapy and photodocumentation. Then, a defined therapeutic plan was based on three months of treatment having two sessions by week in the first month and one session per week during second and third month. Due to the fact that the patient has missed twice, one in the second and another in the third month, all treatment was finished after fourteen combined sessions which lasted an average of thirteen minutes each. Handled electrotherapeutic resources were laser photobiomodulation and plasma jet. Also, there was no need to use anesthetic for doing therapies. Sessions were started with the hygiene of the treated area by using alcoholic solution of clorexidina at $0,5 \%$.

Afterwards, it was applied elite Laser (DMC Importação e Exportação de Equipamentos LTDA, Sao Paulo, Brazil) with wavelength of $660 \mathrm{~nm}$, power of $100 \mathrm{mw}$ and emission of $3 \mathrm{~J} / \mathrm{cm}^{2}$. After, it was applied a LED Ambar (DMC Importação e Exportação de Equipamentos LTDA, Sao Paulo, Brazil) with wavelength of $590 \mathrm{~nm}$ and $200 \mathrm{mw}$ of power in all scalp area screening for 1 minute and 30 seconds. Further, plasma jet was applied and the equipment used was Jett Plasma Lift (Bcmed Equipamentos LTDA, Sao Paulo, Brazil) composed of four appliers and foam electrodes responsible for closing magnetic fields. For therapy it was chosen a flat applicator which has no thermic action. Also, to applying that technique it was necessary to use a conductive gel on the treated area making it possible to take place the plasma jet conduction through a flat tip coupling. In this way, it was done slow, continuous and circular movements on the scalp. In addition, each session of therapy lasted about 5 minutes and the used device was set to work in an intensity of $6 / 8$. During the technique, together with conductive gel, it was administered $1 \mathrm{ml}$ of monodose having growth factors rich in bioidentical peptides, and also, Nanofactor TGF-ß3, Nanofactor EGF, silicon e hyaluronic acid of low molecular weight (MEZZO, Dermabeauty Cosméticos LTDA EPP, Sao Paulo). Among the techniques previously described, it was not recommended any other kind of treatment or dermo cosmetic applying for home care use associated with all therapy. Regarding the methodology to do the analyses it was chosen photo documentation which was done before beginning treatment and just after the last session has been done.

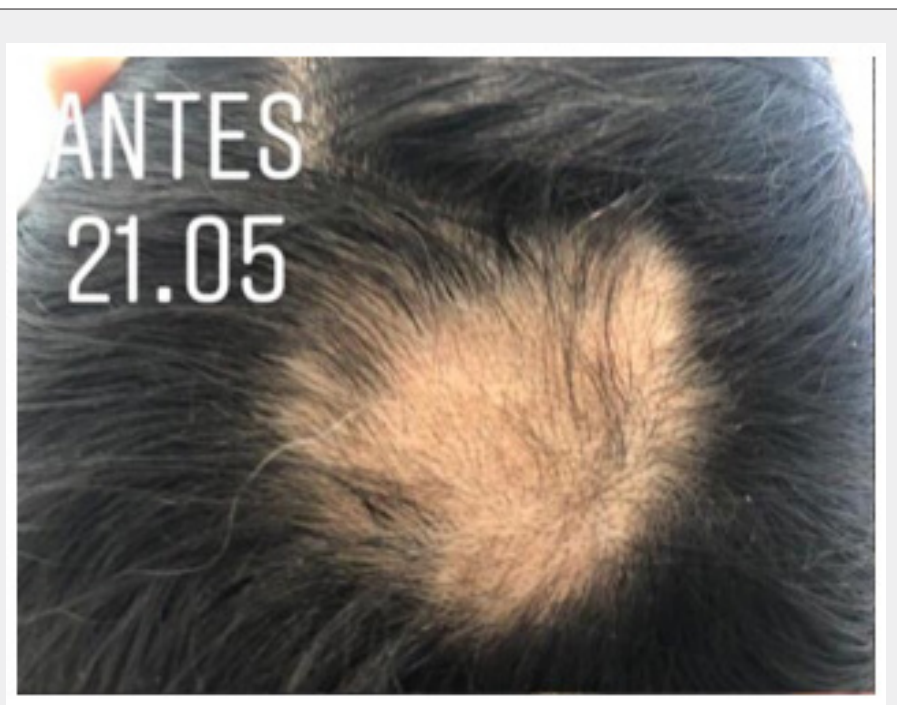

Figure 1: Photo documentation of patient at the first day before starting treatment. 
Besides, the camera used was from a Iphone 8 plus (Apple Inc.) with 12 megapixel and $4608 \times 2592$ resolution. Protocol defined to catch standardized images was having a calibrated operator, taking photographs at the same room from the identical angle under the same lighting incidence at $20 \mathrm{~cm}$ of distance between the camera and the scalp area. That way of assessment does not offer any risk to patients besides being unpainful, low cost and efficient to have a qualitative analysis from the technique regarding comparison found results by image captures of the treated area. Figure 1 shows the first photographic register of the patient caught in the first of treatment before to start therapeutic planning previously described. There was a severe shortening of hair in the coronal region. Figure 2 shows the patient's evolution 23 days after starting therapy associated with a low-power laser of a conductive plasma jet which corresponds to 7 sessions, something around $1 / 3$ of all treatment. At that stage it is possible to realize growth of new hair strands in the area suffering from alopecia areata. Figure 3 presents a significant strand growth in the coronal region. That photo was taken 60 days after beginning therapy, precisely in the $12^{2}$ session regarding $2 / 3$ of the treatment. Observing that picture is almost impossible to notice the area priorly disturbed by the expressive hair loss. Figure 4 proves the efficacy of these treatments applied to the patient suffering from alopecia areata. That record was done in the $14^{\text {th }}$ regards to the last day of the therapy. After finishing the assessment of the treated area, it was demonstrated that it was unnecessary to keep with the sessions since the patient has already shown her scalp region recovered by new strand hair.

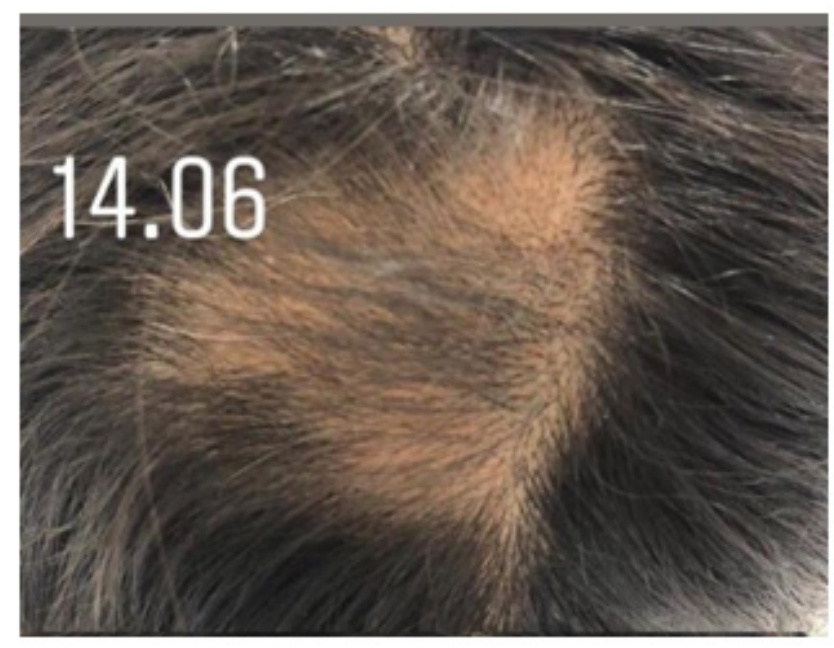

Figure 2: Photo documentation of patient 23 days after beginning treat corresponding to $7^{\mathrm{a}}$ session.

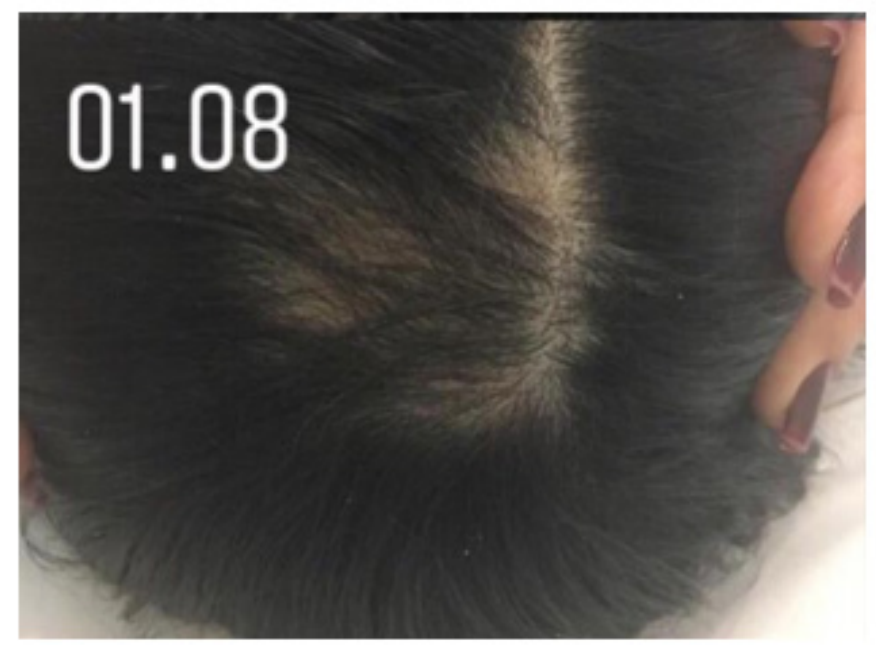

Figure 3: Photo documentation after $12^{\mathrm{a}}$ therapy session. 


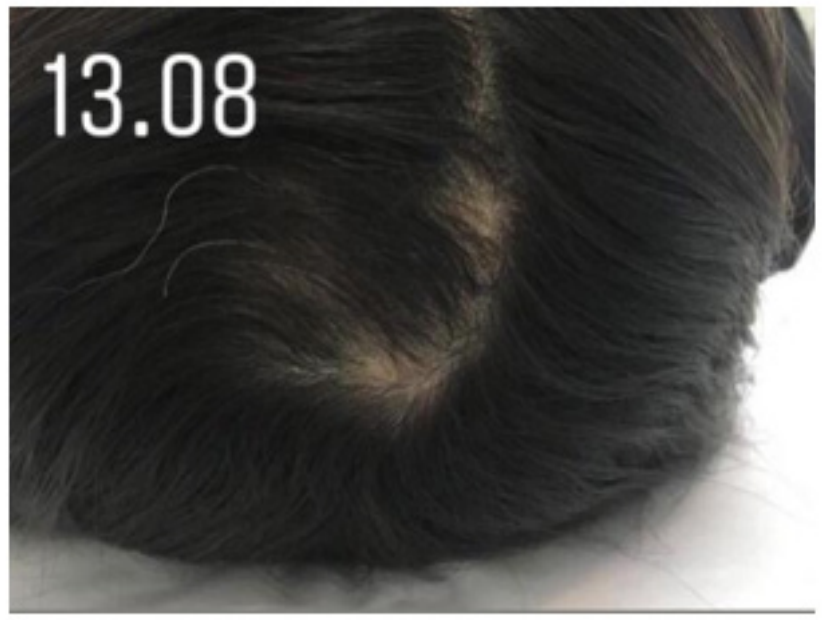

Figure 4: Photo documentation of $14^{\mathrm{a}}$ session, last day of treatment.

\section{Discussion}

The word alopecia comes from "alopekía" which means "naked", and lives up to the most clear signal of that disorder that is hair loss. Also, alopecia is a dermatologic pathology which may be classified as scarring or non-scarring. Then, the scarring one is defined by the absence of lesion in follicles where those are replaced by healing tissue and fibrosis commonly caused by burns, lichen planus disease and others. On the other hand, non-scarring alopecia does not reach the hair follicle's structure but interrupts hair growth triggering strand hair loss [9]. That loss may have many ways, the simplest one with very well-defined spots up to total hair loss which may affect all scalp from where strand hair become [10]. Among the kinds of alopecia, androgenetic is the most common way in both genders' male and female [11]. Another very frequent kind is the alopecia areata which affects almost $2 \%$ of the population in some period of their life [10]. That last type is caused by genetic predisposition and worsened by factors as autoimmune diseases and stresss, and is characterized by the emergence of circle or oval spots in areas without hair with spontaneous remissions and exacerbations [12]. With regard to treatments developed to induce hair growth in cases of alopecia areata, photobiomodulation has been shown as the most efficient. Laser is a device composed of substances from liquid, solid or gas form that manufacture beams of light when stimulated by a source of energy usually called as "laser ray" [6]. Then, laser therapy of low-power takes place by exposing the scalp area to lighting energy and this energy has the capacity to change biomolecules through photochemical reactions acting directly over capillary matrix [13]. Also, these lasers produce analgesic effects beyond biostimulation and anti inflammatory [6]. Photobiomodulation applies a bio-stimulating action in the tissue repair process inducing mitotic activity of epithelial cells and fibroblasts that will be encouraged to produce collagen. Further, it inhibits secretion of some chemical mediators, modifies capillary density and increases local microcirculation $[6,9]$.

Physical plasma are ionized gases (excited) which contain different concentrations with low molecular weight of reactive atoms, ions and molecules. Once electrons are withdrawn from atoms and molecules, these particles may change their stage and become plasma [14]. Some studies in cell culture prove that a treatment using plasma might influence wounds' healing not only by reducing bacteria colonization but for effects straight on epidermal and dermal cells [8]. Additionally, it has other benefits for treating isochronies, photoaging, sagging skin and acne scars [7]. Plasma jet application also brings benefits for healing wounds and regenerative processes due to its high concentrations of nitric oxide (NO) which might exogenously be created by plasma. Among others, vasodilation and normalized microcirculation, direct bactericidal effects, improvements on nervous conductive speed, stimulations of fibroblast and vase growth area attributed to induction of cytokines and growth factors [8]. Thus, using plasma combined with photobiomodulation and growth factors rich in bioidenticals peptides has shown a powerful combination for treating alopecia as presented by that clinic report.

Human growth factors (HGF) play in many events evolving complex interactions between organism cells to restore inside and outside physical integrity aiming for healing [15]. They can be proteins or cytokines which may link to receptors on cell surfaces activating cell proliferation and/or differentiation $[15,16]$. Thus, HGF might act as alert, activators or deactivators of different cell activity as well as to stimulate angiogenesis and cell growth. They are mainly found in tissue which are crossing cell renewing or healing process [16]. Hyaluronic acid (HA) is a glycosaminoglycan compound composed of glucuronic acid. It has several biological properties such as ability to retain water and viscoelastic behavior which make HA very suitable for many techniques, medical and 
pharmaceutical applications [17]. Also, HA may be of low or high molecular weight. But, still there is no consent in literature with regard to the efficacy of using hyaluronic acid taking into account its molecular weight [18]. However, using low molecular weight HA leads to a major permeability and consequently, it retains more water on the intercell matrix of conjunctive tissue in comparison to high molecular weight HA [19]. In this research, it was used monodose composed of hyaluronic acid of low molecular weight as one of the main active ingredients beyond growth factors rich in bioidentical peptides which helped in growing new strand hair. With regard to photography, it is an important tool for esthetic treatments and fundamental to follow up all evolution over the therapy as far as comparing results [20]. Because alopecia is a pathology that causes visible hair loss, photo documentation has been known as a cheap, effective and non-painful way to present treatment's efficacy. Therefore, the use of photo documentation still needs such standardization to make with the unique variable to be noticed in the pictures is the results from therapy. Thus, lighting, distance between camera and patient, position and background's image have to be equivalent between all images to be compared [21].

\section{Conclusion}

Comparative analyses of photos demonstrated that the associated therapy of photo-biomodulation with plasma jet has been efficient in treating alopecia areata in a woman patient. It may suggest that results came from through biomodulation effects of the therapeutic resources. Also, it came from associated dermo cosmetic given during therapy which was able to potentialize results of stimulus offered by equipment used along treatment.

\section{References}

1. Silva RT (2011) Medicamentos antiandrógenos de uso oral para o tratamento da alopecia androgênica. Orientadora: Sílvia Stanisçuaski Guterres. Tese (Graduação em Farmácia) - Universidade Federal do Rio Grande do Sul, Brazil.

2. Santana JV, Lopes MV, Santos BAJ (2017) Relação entre Estresse e Alopercia Androgenética: Uma Revisão da Literatura. Id on Line Rev Psic 11(35): 01-17.

3. Freitas CAM, Cohen JFV (2018) Fisiopatologia de alopecia androgenética: uma revisão da literatura. Saber Científico 7(2): 1-7.

4. Assis PRGR, Dantas LV (2018) Tratamento de alopecia androgenética masculina com drug delivery por microagulhamento: Relato de Caso. Fisioterapia Brasil 19(4): 546-54.
5. Silva LBP, Santos BA (2018) Uso do Laser de baixa intensidade no tratamento da Alopecia Androgenética: Uma Revisão Bibliográfica. Id on Line Revista Multidisciplinar e de Psicologia 12(40): 1065-1081.

6. Foster KW, Moy RL, Fincher EF (2008) Advances in plasma skin regeneration. Jornal of Cosmetic Dermatology 7(3): 169-179.

7. Julia HJ, Morfill G, Landthaler M, Stolz W, Isbary G, et al. (2010) Medicina Plasma: possíveis aplicações em dermatologia. Jornal (C) Blackwell Verlag GmbH 8(12): 968-976.

8. Hochman B, Nahas FX, Ferreira LMN (2005) Fotografia aplicada na pesquisa clínico-cirúrgica. Acta Cirúrgica Brasileira 20(2): 19-25.

9. Nogueira ES, Pereira LP, Bacelar I (2018) Tratamentos para alopecia androgenética e alopecia areata: microagulhamento, laser de baixa intensidade e fatores de crescimento - revisão de literatura. Revista Saúde em Foco (10): 620-631.

10. Rivitti EA (2005) Alopecia areata: revisão e atualização. An. Bras. Dermatol 80(1): 57-68.

11. Brenner FM, Seidel G, Hepp T (2011) Entendendo a alopecia androgenética. Surg Cosmet Dermatol 3(4): 329-337.

12. Amos G, Kalish RS (2006) Alopecia Areata: A tissue specific autoimmune disease of the hair follicle. Autoimmunity Reviews 5(1): 64-69.

13. Paulillo MP, Talhati F (2018) Alopecia androgenética masculina e tratamentos estéticos. Revista Diálogos Interdisciplinares 7(4): 3-5.

14. Porciuncula M, Menezes MSO, Gusman H, Simão RA, Prado M (2015) Tecnologia de plasma na Odontologia: revisão de literatura. Rev Bras Odontol 72(1-2): 100-103.

15. Souza MA, Burak E (2017) Os benefícios dos fatores de crescimento aplicados nas rugas periorbitais. Orientador: Renato Guimarães Machado. Tese (Graduação em Bacharelado em Estética) - Universitário Hermínio da Silveira, Brazil.

16. Silva BMF, Bolda JM, França AJ (2011) 0 uso de fatores de crescimento em produtos cosméticos para tratamento do envelhecimento cutâneo. Univali, Balneário Camboriú, Brazil.

17. Moraes BR, Bonami JA, Romualdo L, Comune AC, Sanches RA (2017) Ácido hialurônico dentro da área de estética e cosmética. Revista Saúde em Foco (9): 552-562.

18. Oliveira MZ, Albano MB, Namba MM, Cunha LAM, Goncalves RR, et al. (2014) Efeito dos ácidos hialurônicos como condroprotetores em modelo experimental de osteoartrose. Revista Brasileira de Ortopedia 49(1): 62-68.

19. Oligo HA (2017) Nutrifarm. Grande São Paulo, São Paulo, Brazil

20. Dias NMZ, Jung PA, Oliveira EC (2017) A importância da padronização dos registros fotográficos da face. Revista de Iniciação Científica, Tecnológica e Artística Edição Temática em Saúde e Bem-estar 6(5): $31-43$.

21. Pinheiro MVB (2013) A fotografia na cirurgia dermatológica e na cosmiatria - Parte I. Surgical \& Cosmetic Dermatology 5(2): 101-108. 
This work is licensed under Creative Commons Attribution 4.0 License DOI: 10.19080/JOJDC.2021.04.555629

\section{Your next submission with Juniper Publishers} will reach you the below assets

- Quality Editorial service

- Swift Peer Review

- Reprints availability

- E-prints Service

- Manuscript Podcast for convenient understanding

- Global attainment for your research

- Manuscript accessibility in different formats

( Pdf, E-pub, Full Text, Audio)

- Unceasing customer service

Track the below URL for one-step submission

https://juniperpublishers.com/online-submission.php 